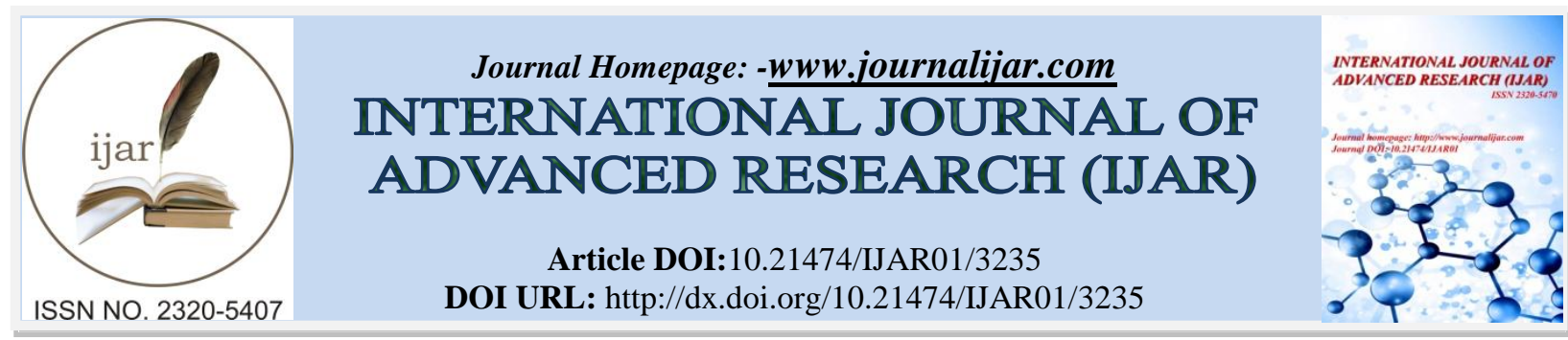

RESEARCH ARTICLE

\title{
DIFFERENCE IN PERCEPTION OF AVOIDANCE STRATEGIES AGAINST SEXUAL HARASSMENT AMONG UNDERGRADUATE FEMALES STUDENTS IN WOMEN AND CO-EDUCATIONAL COLLEGE IN DELHI.
}

\author{
Ms. Keerthi Mohanan ${ }^{1}$, Dr. Sandhya Gupta ${ }^{2}$ and Dr. Rajesh Sagar ${ }^{3}$. \\ 1. Principal Investigator: Clinical instructor, Institute of nursing, Kgmu Lucknow \\ 2. Lecturer College of nursing, AIIMS, New Delhi. \\ 3. Professor, Dept. of Psychiatry, AIIMS New Delhi.
}

\section{Manuscript Info}

(........................

Manuscript History

Received: 19 December 2016

Final Accepted: 25 January 2017

Published: February 2017

Key words:-

Young female adults, Awareness of sexual harassment, Avoidance strategies

for sexual harassment.

\section{Abstract}

Young female adults are most vulnerable to harassment and violence towards them. These strategies could be learned either from circumstances surrounding or by some organized training. A descriptive, cross sectional survey design on 200 female undergraduate students from two women colleges and two co-educational colleges from University of Delhi, India was undertaken using convenient sampling technique. A semi structured interview and a structured awareness questionnaire developed by researcher was used. Results:Awareness was not found to be correlated to any of the variables and the type of college (women or co-educational college) they attended.Females in coeducational college had more awareness regarding description of sexual harassment, identification of high risk situation, actions against sexual harassment and prevention of sexual harassment. Female in women college had a view to ignore sexual harassment incidence than co-educational college females. Implications: Youth need to be aware and avoid risk factors for safety of self and how to report the incident to prevent further harassment. Conclusion: Awareness about avoidance strategies of coeducational college females was more in some selected aspects of awareness about avoidance of sexual harassment.

Copy Right, IJAR, 2017,. All rights reserved.

\section{Introduction:-}

Strategies for avoidance of sexual harassment are essential for everyone, whether female or male right from childhood. Strategies are identification of risk before the incidence occurs. Perception of threat from a situation makes an individual alert and decides when to take action for self safety ${ }^{i}$. The situation of facing harassment might differ in type of college females are studying. In co educational colleges females are more exposed to situations of sexual harassment and they learn from their experiences and are prepared to deal such situations in future where as in all women college female tend to ignore such situations to avoid embarrassment. A study done among college student in Bangalore reported that students from co-education colleges faced sexual harassment more as compared to those who study only in Women Colleges ${ }^{\text {ii }}$.The objectives of the study were:To find out the association between awareness of young female adults about strategies for avoidance of sexual harassment with type of college (women/Co-ed). 


\section{Methodology:-}

A quantitative approach, cross sectional survey was used and 200 young female adults studying in degree courses in the age group of 17-21 years from four selected colleges of Delhi University, two co-educational colleges and two women colleges were included by convenient sampling method. Students unwilling to participate were excluded from the study.

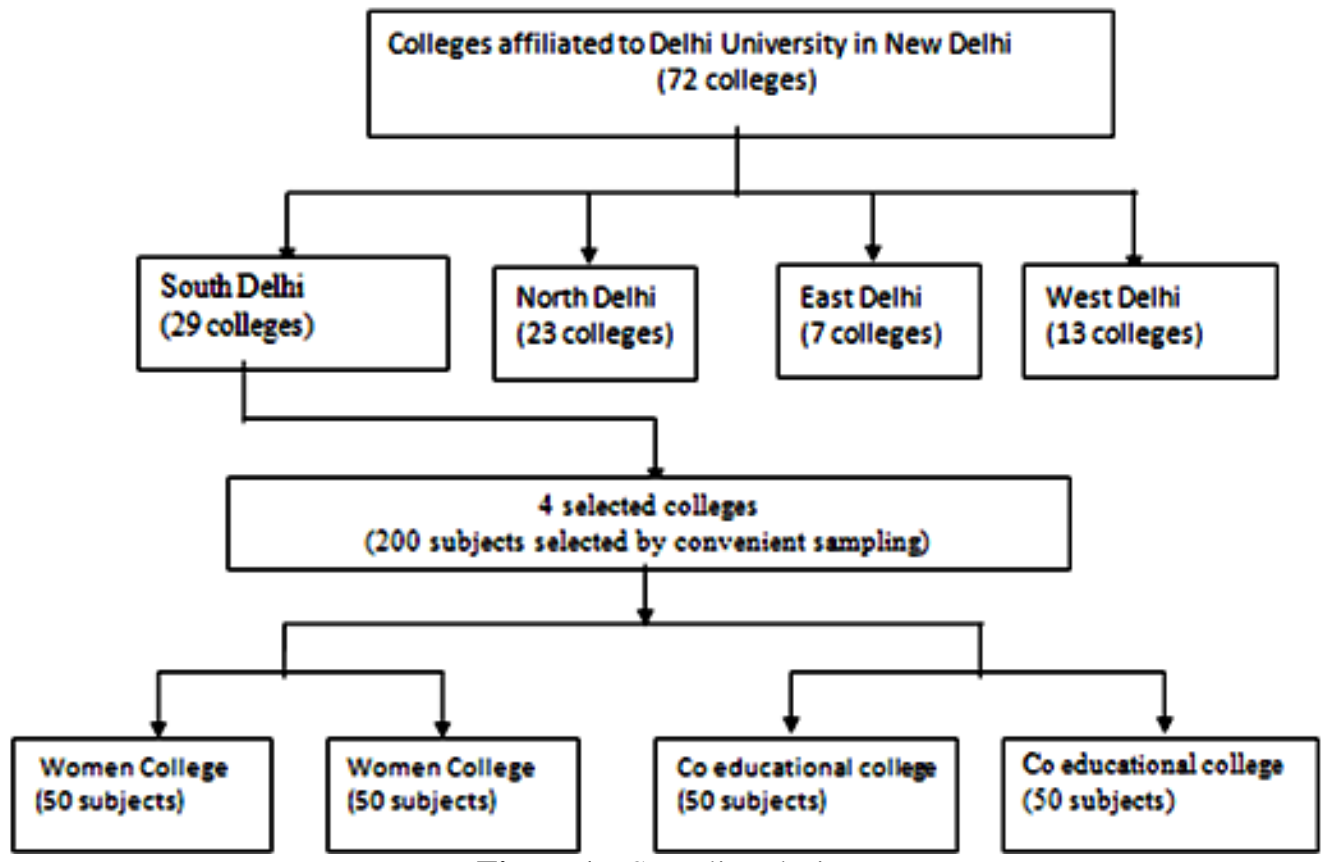

Fig no.1:- Sampling design

\section{Tools used:-}

Subject data sheet: structured questionnaire for socio demographic profile and selected variables of the subjects and informed consent form. Tool 1: Interview schedule (IS)( 05 items) to assess previous experience with sexual harassment either on self or observed by subjects and preferred action against sexual harassment and whom they would like to inform in a situation of sexual harassment. Tool 2: Structured questionnaire (AQ) (40items-12 single answer questions and 28 multiple answer questions) for assessing the awareness of Young female adults about avoidance strategies for sexual harassment divided into seven groups (Table no 1). Each item was given a score of one and maximum score could be 172. The awareness was scored on five point scale, some<36, slightly(36-72), fair (73-108),just enough (109-144), good(145-172) and was further categorized as awareness levels- Excellent- good awareness scores, Satisfactory-just enough awareness scores and less than satisfactory-fair awareness scores. The content validity was done and reliability of the tool was assessed by test retest method by McNemer Chi squaretest and $\mathrm{p}$ value was found not significant for all questions. Pilot study was done on 30 subjects and was found to be feasible. Ethical clearance was obtained from ethical committee of AIIMS, New Delhi and informed consent was obtained from subjects. The data was collected from June to November 2014. Data were analysed using STATA 16.1 by appropriate descriptive statistics-frequency, percentage and inferential statistics- Pearson's chi square test and Fisher exact test.

\section{Description of the subjects:-}

Mean age of the subjects was $18.77 \pm 1.118$ years and the maximum age was 21 years and minimum was 17 years. All (100\%) subjects were unmarried. Almost half (54\%) of the subjects monthly family income was greater than Rs $60,000 /$ - Most $(89.5 \%)$ of the subject belonged to Hindu religion and Most (65\%) of the subjects were residing in urban area in Delhi NCR .

\section{Results:-}

Nearly half of subjects in women's college had slight awareness and one tenth of subjects had just enough awareness about avoidance strategies for sexual harassment. Among subjects from co- educational college $34 \%$ of subjects had slight awareness, half of subjects had fair awareness and one fifth of the subjects had just enough 
awareness about avoidance strategies for sexual harassment. There was no statistically significant difference between awareness of the subjects studying in women's college and coeducational college hence the knowledge of two groups is comparable. (table no 1)

Out of total 40 item awareness questionnaire a statistically significant difference was found in 13 questions among awareness of subjects about avoidance strategies for sexual harassment in women's college and co-educational college. Women in coeducational college had more awareness than in women only colleges in araea like definition of sexual assault, danger of sexual harassment from known to persons like neighbours and co-workers, place like crowded markets and office of officials need to be avoided as a prevention method, regarding informing media like radio and print media ragrding incidence and were more aware regarding legal facilities against sexual harassment, regarding alarming signs for a date rape and importance of raising an alarm and asking help from others in an incidence of sexual harassment. Whereas females of women college had had a view to ignore an incidence of sexual harassment. (table no.2)

Table no.1:-Association of awareness of avoidance strategies among two women's college and two co-educational college $(\mathrm{n}=200)$

\begin{tabular}{|l|l|l|l|l|}
\hline \multirow{2}{*}{ Group } & \multicolumn{4}{|c|}{ Awareness scores } \\
\cline { 2 - 5 } & Slight & fair & Just enough & P value \\
\hline $\begin{array}{l}\text { Females in women's college } \\
(\mathrm{n}=100)\end{array}$ & $41(41 \%)$ & $45(45 \%)$ & $14(14 \%)$ & $\mathrm{p}=0.573$ \\
\hline $\begin{array}{l}\text { Female in co-educational } \\
\text { college(n=100) }\end{array}$ & $34(34 \%)$ & $49(49 \%)$ & $17(17 \%)$ & \\
\hline
\end{tabular}

Table no.2:- Comparison of awareness of subjects about avoidance strategies for sexual harassment among two women college and two co-educational colleges $(\mathrm{n}=200)$

\begin{tabular}{|c|c|c|c|c|}
\hline $\begin{array}{l}\text { Areas of } \\
\text { avoidance } \\
\text { strategies }\end{array}$ & Awareness of avoidance of sexual harassment & $\begin{array}{l}\text { Group } \\
1(n 1=100)\end{array}$ & $\begin{array}{l}\text { Group } \\
2(\mathrm{n} 2=100)\end{array}$ & p value \\
\hline $\begin{array}{l}\text { Description of } \\
\text { sexual harassment }\end{array}$ & $\begin{array}{l}\text { Sexual assault is sexual contact that uses force or } \\
\text { coercion }\end{array}$ & 41 & 67 & 0.005 \\
\hline \multirow[t]{4}{*}{$\begin{array}{l}\text { Identification of } \\
\text { high risk situation }\end{array}$} & $\begin{array}{l}\text { There is need to be aware from neighbours for fear of } \\
\text { sexual harassment }\end{array}$ & 48 & 62 & $<.0001$ \\
\hline & $\begin{array}{l}\text { There is need to be aware from co-workers for fear of } \\
\text { sexual harassment }\end{array}$ & 49 & 64 & 0.047 \\
\hline & Sexual harassment can take place in crowded market & 44 & 59 & 0.032 \\
\hline & $\begin{array}{l}\text { One should avoid office of official due to fear of } \\
\text { harassment }\end{array}$ & 25 & 40 & 0.024 \\
\hline \multirow[t]{6}{*}{$\begin{array}{l}\text { Actions against } \\
\text { sexual harassment }\end{array}$} & $\begin{array}{l}\text { If sexual harassment occurs outside office building by } \\
\text { work related personnel, victim can file for harassment }\end{array}$ & 83 & 96 & .003 \\
\hline & $\begin{array}{l}\text { Victim of sexual harassment should inform media like } \\
\text { radio }\end{array}$ & 24 & 13 & 0.045 \\
\hline & $\begin{array}{l}\text { Victims of sexual harassment should inform media like } \\
\text { newspaper journalist }\end{array}$ & 30 & 14 & 0.006 \\
\hline & $\begin{array}{l}\text { Women facing sexual harassment suffer from mental } \\
\text { distress }\end{array}$ & 85 & 94 & 0.038 \\
\hline & Aware of legal facilities against sexual harassment & 34 & 50 & 0.022 \\
\hline & Victim should ignore unwanted sexual advances & 17 & 07 & 0.030 \\
\hline $\begin{array}{l}\text { Prevention of date } \\
\text { rape }\end{array}$ & $\begin{array}{l}\text { Getting a double meaning from friend on a date is } \\
\text { alarming sign for possible harassment }\end{array}$ & 50 & 66 & 0.022 \\
\hline $\begin{array}{lr}\text { Training } & \text { to } \\
\text { prevent } & \text { and } \\
\text { combat } & \text { sexual } \\
\text { harassment } & \end{array}$ & $\begin{array}{l}\text { Raising an alarm and taking help from others would be } \\
\text { most useful to avoid sexual harassment }\end{array}$ & 56 & 70 & 0.040 \\
\hline
\end{tabular}




\section{Conclusion:-}

The female studying in co-educational colleges seems to be more prepared to deal a situation of sexual harassment. Women colleges need to introduce more awareness among their students about avoidance of sexual harassment.

\section{Implications:-}

School and college teachers need to identify early signs of harassment and take preventive steps in college premises. Youth need to be aware and avoid risk factors for safety of self and how to report the incident to prevent further harassment.In all institutional settings there need to identify signs of harassment, counsel the victim and referring to social worker and counselors for further services. Gender sensitization should be included in curriculum and in service education.

\section{Remedial actions taken:-}

During data collection all doubt pertaining to sexual harassment and avoidance strategies were explained if asked by subjects.

\section{Limitations:-}

No follow up counseling could be given to those subjects who required it due to time constraints.

\section{Recommendations:-}

Similar study can be done with larger sample size, with a qualitative approach, among different college going population, general population among boys and men.

\footnotetext{
${ }^{i}$ Strategies for preventing sexual abuse [Internet]. [cited 2015 Jan 17]. Available from: https://www.kstate.edu/media/webzine/Didyouhearyes/Strategies.html

iic"Research Study on college student perspective of Sexual Harassment in Bangalore City" supported by NCW ( 2012-13) | Women Power Connect [Internet]. [cited 2015 Jun 8]. Available from: http://www.womenpowerconnect.org/?page_id=388
} 